Original article

DOI: $10.19027 /$ jai.18.1.1-8

\title{
The digestibility of biofloc meal from African catfish culture medium as a feed raw material for Pacific white shrimp
}

\section{Kecernaan tepung bioflok yang berasal dari media pemeliharaan ikan lele sebagai bahan pakan udang vaname}

\author{
Julie Ekasari*, Muhammad Agus Suprayudi, Putri Elas, Reza Karunia Senja \\ Department of Aquaculture, Faculty of Fisheries and Marine Science, IPB University \\ *Corresponding author : j_ekasari@ipb.ac.id
}

(Received December 12, 2018; Accepted December 21, 2018)

\begin{abstract}
This study was conducted to evaluate the digestibility of biofloc meal collected from catfish culture as a feed raw material for Pacific white shrimp Litopenaeus vannamei diet. A basal feed with $43 \%$ crude protein content was used as a control diet and mixed with $2 \%$ of binders and $0.5 \%$ of $\mathrm{Cr}_{2} \mathrm{O}_{3}$ as a marker for digestibility. The experimental diets were made by mixing $67.5 \%$ of the basal diet with $30 \%$ of biofloc meal, $2 \%$ of binders and $0.5 \%$ of $\mathrm{Cr}_{2} \mathrm{O}_{3}$. Nine units of glass tanks $(90 \mathrm{~cm} \times 40 \mathrm{~cm} \times 35 \mathrm{~cm})$ filled with $100 \mathrm{~L}$ seawater were used as the experimental culture units. White shrimp with an average body weight of $5.61 \pm 0.09 \mathrm{~g}$ was randomly distributed to each experimental tank at a density of 20 shrimp/tank. The feed was offered at a level of $5 \%$ shrimp biomass per day at a frequency of four times a day. The results showed that the dry matter digestibility of feed with $30 \%$ biofloc meal in shrimp were similar to that of the reference diet. However, protein and fat digestibility of feed containing biofloc meal were considerably higher than those of the reference diet. Feeding shrimp with $30 \%$ biofloc meal diet resulted in higher survival and specific growth rate and lower feed conversion ratio than those of the control. The digestibility of bioflocs dry matter, protein and lipid in Pacific white shrimp obtained in this study were 54.9\%, $76.3 \%$ and $79.3 \%$, respectively.
\end{abstract}

Keywords: biofloc, digestibility, catfish, shrimp

\begin{abstract}
ABSTRAK
Penelitian ini dilakukan untuk mengevaluasi kecernaan tepung bioflok yang diambil dari media pemeliharaan ikan lele sebagai bahan pakan udang vaname Litopenaeus vannamei. Pakan yang mengandung kadar protein $43 \%$ digunakan sebagai pakan control dan dicampur dengan $2 \%$ binder dan $0,5 \% \mathrm{Cr}_{2} \mathrm{O}_{3}$ sebagai marker untuk kecernaan. Pakan perlakuan dibuat dengan mencampurkan $67.5 \%$ pakan control dengan $30 \%$ tepung bioflok, $2 \%$ binder dan $0,5 \% \mathrm{Cr}_{2} \mathrm{O}_{3}$. Penelitian menggunakan sembilan unit akuarium $(90 \mathrm{~cm} \times 40 \mathrm{~cm} \times 35 \mathrm{~cm})$ yang diisi $100 \mathrm{~L}$ air laut. Udang vaname dengan bobot rata-rata 5,61 $\pm 0,09 \mathrm{~g}$ ditebar secara acak pada setiap akuarium perlakuan pada kepadatan 20 ekor/akuarium. Pakan diberikan dengan tingkat pemberian pakan 5\% biomassa per hari sebanyak empat kali sehari. Hasil penelitian ini menunjukkan bahwa kecernaan pakan dengan 30\% tepung bioflok tidak berbeda nyata dengan pakan acuan. Namun kecernaan protein dan lemak pakan yang mengandung tepung bioflok terlihat lebih tinggi daripada pakan kontrol. Pemberian pakan dengan tepung bioflok sebanyak $30 \%$ juga menghasilkan tingkat kelangsungan hidup, laju pertumbuhan spesifik udang dan rasio konversi pakan yang lebih baik daripada udang yang diberi pakan kontrol. Kecernaan bahan, protein dan lemak tepung bioflok pada udang yang didapat dalam penelitian masing-masing adalah $54,9 \%, 76,3 \%$, dan 79,3\%.
\end{abstract}

Kata-kata kunci: bioflok, ikan lele, kecernaan, udang 


\section{INTRODUCTION}

Biofloc-based aquaculture system has been widely studied and applied. This system applies the heterotrophic microbial conversion of nutrient waste in aquaculture system into microbial biomass by the addition of organic carbon source (De Schryver et al., 2008). The microbial biomass generated in this system is expected to be utilized back by the cultured organism in situ. In this regard, the nutrient utilization efficiency in biofloc-based aquaculture system can be enhanced and the level of nutrient wastes that maybe harmful for the cultured organism can be maintained at low concentration. However, the application of biofloc technology in an intensive aquaculture system can be limited by the high accumulation of microbial biomass in the system that may bring about negative impacts to the cultured species such as competition in oxygen consumption, the potential of gill occlusion and unstable water quality (Ekasari et al., 2014a). One of the strategies to utilize the excess biomass in biofloc-based aquaculture system is by harvesting this biomass and utilizing it as a feed ingredient.

Bioflocs are an aggregate of microorganisms, including bacteria, yeast, microalgae, micro and macroinvertebrates, extrapolymeric substances and suspended solids (De Schryver et al., 2008). Studies have showed that the nutritional composition of bioflocs was considerably sufficient to meet the requirement of some aquaculture species including shrimp (Ekasari et al., 2014b; Kuhn et al., 2010). Ekasari et al. (2014a) reported that according to its essential amino acids index, bioflocs can be considered as a good protein source for shrimp.

The use of biofloc meal as a raw material in shrimp diet has been reported by previous studies (Kuhn et al., 2016; Glencross et al., 2014; Glencross et al., 2015; Van Den Hende et al., 2014; Anand et al., 2014; Bauer et al., 2012, Lobato et al., 2019). Kuhn et al. (2016) recently reported that bioflocs meal generated from confectionary food effluent water could be used to replace soybean up to $30 \%$ and fishmeal up to $20 \%$ in shrimp diet. This clearly showed that bioflocs meal could be used to replace fishmeal, which was has been considered as a limited, un-environmentally friendly and unsustainable aquaculture feed ingredient, and therefore a potential feed ingredient for shrimp. Recent study reported that the addition of microbial biomass could act as a feeding stimulant in tilapia (Simon et al., 2019). Furthermore, the consumption of microbes associated in bioflocs may release of microbe associated molecular patterns (MAMPs) such as B-1,3-glucan, lipopolysaccharides and peptidoglycan, which may stimulate the nonspecific immune system of the host (Xu \& Pan, 2013; Xu \& Pan, 2014; Kheti et al., 2017). The present study explored the potential use of bioflocs derived from biofloc-based catfish intensive production as a feed ingredient for shrimp. The study included a digestibility test to evaluate the nutrient digestibility of bioflocs meal by shrimp.

\section{MATERIALS AND METHODS}

\section{Microbial biomass production}

Microbial biomass was collected from bioflocbased intensive catfish production. The catfish was cultured at the density of 500-1000 fish/ $\mathrm{m}^{3}$ and fed with commercial feed with a protein content of $35 \%$ at a feeding frequency of three times daily. Molasses with a carbon content of $40-50 \%$, was added daily to stimulate the growth of heterotrophic microbial a $\mathrm{C} / \mathrm{N}$ ratio of 15 . After about 30 days of culture, microbial biomass was collected and air-dried. Microbial biomass was subsequently oven dried at $50^{\circ} \mathrm{C}$ until the moisture reached a level of $10 \%$.

\section{Experimental setup}

Shrimp postlarvae ( $\left.\mathrm{PL}_{12}\right)$ was obtained from a local hatchery at Labuan Banten and maintained at a semi-outdoor tank $(2 \mathrm{~m} \times 7 \mathrm{~m} \times 1 \mathrm{~m})$ until it reached the desirable size for about 45 days. The shrimp was acclimatized to laboratory condition and experimental diets for about seven days prior to experimentation. Glass aquaria $(90 \mathrm{~cm} \times 40$ $\mathrm{cm} \times 35 \mathrm{~cm}$ ) previously filled with $100 \mathrm{~L}$ seawater were used as the experimental culture units.

Digestibility test of the microbial biomass meal on shrimp was performed based on the procedures described in Molina-Poveda et al. (2015) using chromium oxide as an inert marker. The formula and the compositions of the reference diet used in this study are presented in Table 1.

Shrimp juvenile at an initial average body weight of $5.61 \pm 0.09 \mathrm{~g}$ were randomly distributed into nine units of $60 \times 40 \times 50 \mathrm{~cm}$ aquarium previously filled with $100 \mathrm{~L}$ of seawater at a density of 20 shrimp per aquarium. Feeding was offered four times daily at a level of 5\% of the total biomass per aquarium. Faeces collection was conducted for 14 days starting on day-3 after stocking by siphoning out the faecal material from 
Table 1 . The composition of reference diet

\begin{tabular}{lc}
\hline & $(\%)$ \\
\hline Fishmeal & 24.00 \\
Soybean meal & 10.00 \\
Corn glutten meal & 10.00 \\
Meat bone meal & 12.00 \\
Pollard & 24.93 \\
Wheat meal & 10.50 \\
Fish oil & 4.00 \\
Lecithin & 1.50 \\
Cholesterol & 0.20 \\
Premix & 2.02 \\
Astaxantine & 0.25 \\
Polymethylolcarbamide & 0.60 \\
\hline
\end{tabular}

the bottom of the tank. The collected faecal matter was subsequently analysed for dry matter, protein, lipid and $\mathrm{P}$ apparent digestibility according to the method described in Cho \& Slinger (1979).

Apparent digestibility coefficient (ADC) for dry matter, crude protein, crude lipid, and phosphorus were calculated according to Cho \& Slinger (1979) with the following equation:

$$
\% \mathrm{ADC}_{\mathrm{n}}=100-\left[100 \times\left(\frac{\% \mathrm{C}_{\text {diet }}}{\% \mathrm{C}_{\text {faces }}}\right) \times\left(\frac{\% \mathrm{~N}_{\text {faeces }}}{\% \mathrm{~N}_{\text {diet }}}\right)\right]
$$

where $\mathrm{C}$ is chromic oxide and $\mathrm{N}$ is the concentration of the considered nutrient (dry matter, crude protein, crude lipid, and phosphorous) in the diet or in the faeces (\% dry basis). The apparent digestibility coefficients of the test ingredient for dry matter, crude protein, crude lipid, and $\mathrm{P}$ were calculated according to the following equation (NRC, 2011):

$\% \mathrm{ADC}_{\mathrm{BM}}=\mathrm{ADC}_{\text {test diet }}+\left[\left(\mathrm{ADC}_{\text {test diet }}-\mathrm{ADC}_{\text {ref. diet }}\right) \times \frac{0.7 \mathrm{xN}_{\text {ref }}}{0.3 \mathrm{xN}_{\text {ing }}}\right]$

where $\mathrm{ADC}_{\text {testdiet }}$ and $\mathrm{ADC}_{\text {ref.diet }}$ are apparent digestibility coefficients of the test ingredient; $\mathrm{N}_{\text {ref }}$ and $\mathrm{N}_{\text {ing }}$ are the concentrations of the nutrient (dry matter, crude protein, crude lipid, $\mathrm{P}$ and amino acids) in the reference diet and in the test ingredient, respectively.

The water quality in the shrimp culture medium was maintained by siphoning unconsumed feed materials and regular water exchange at a level of $30 \%$ per day. The water quality parameters were measured every week throughout the experimental period and the results showed that the water quality was generally within acceptable range (Table 2).
Table 2. Ranges of water quality parameters in the experimental units

\begin{tabular}{lc}
\hline \multicolumn{1}{c}{ Parameter } & Range \\
\hline Dissolved oxygen $(\mathrm{mg} / \mathrm{L})$ & $5.02-5.89$ \\
Temperature $\left({ }^{\circ} \mathrm{C}\right)$ & $29-30$ \\
$\mathrm{pH}$ & $6.95-7.41$ \\
Nitrite $(\mathrm{mg} / \mathrm{L})$ & $0.26-0.55$ \\
Nitrate $(\mathrm{mg} / \mathrm{L})$ & $0.22-0.35$ \\
Total ammoniacal nitrogen $(\mathrm{mg} / \mathrm{L})$ & $0.02-0.04$ \\
\hline
\end{tabular}

\section{Biochemical analysis}

Proximate compositions of feed, bioflocs and shrimp were determined according to Takeuchi (1988). The amino acid composition of the feed and faeces were measured by using high performance liquid chromatography (HPLC) at Saraswanti Indogenetech according to AOAC (2005). The proximate and amino acids compositions of the biofloc meal and the experimental diets are presented in Table 3.

\section{Data analysis}

All survival data was arcsine transformed. Homoscedasticity and normality of all data were assessed using Levene's test and a KolmogorovSmirnov test, respectively. As all data was normally distributed and the variances of the variables were equal, the data were analysed using one-way ANOVA. Statistical analyses were performed using a statistical software StatPlus version 2009 at a significance level of 0.05 . Significant differences between treatments were determined using a post-hoc Duncan test.

\section{RESULTS AND DISCUSSION}

\section{Results}

The shrimp survival were similar amongst treatments $(80.0-86.7 \%)(\mathrm{P}>0.05)$. The specific growth rate of the shrimp were similar in both treatments at an average level of $2.04 \%$ /day. In general, the digestibility of dry matters, protein and lipids of diets containing $30 \%$ of bioflocs meal was comparable to that of the reference diet. However, a significantly higher P digestibility was observed in the feed with bioflocs meal $(\mathrm{P}<0.05)$ (Figure 1).

Interestingly the essential amino acids digestibility of the diet containing microbial meal was generally higher than that of the reference diet (Table 4).

Overall the digestibility of dry matter, lipid, protein and phosphorus of biofloc meal in 
Table 3. Proximate and amino acids compositions of biofloc meal and the experimental diets in digestibility test

\begin{tabular}{|c|c|c|c|}
\hline & \multirow{2}{*}{ Biofloc meal } & \multicolumn{2}{|c|}{ Experimental diets } \\
\hline & & Reference & Microbial biomass \\
\hline \multicolumn{4}{|l|}{ Proximate composition } \\
\hline Moisture (\%) & 8.94 & 6.00 & 5.50 \\
\hline Protein $(\% \mathrm{DW})$ & 16.48 & 43.03 & 42.44 \\
\hline Lipid (\% DW) & 3.35 & 3.97 & 3.98 \\
\hline Fibre (\% DW) & 16.92 & 4.63 & 10.16 \\
\hline Ash (\% DW) & 11.16 & 8.5 & 10 \\
\hline Nitrogen free extract (\% DW) & 43.15 & 33.87 & 27.92 \\
\hline \multicolumn{4}{|l|}{ Dispensable amino acids (\%) } \\
\hline Aspartic acid & - & 3.59 & 3.46 \\
\hline Glutamic acid & - & 6.92 & 6.45 \\
\hline Serine & - & 1.65 & 1.66 \\
\hline Glycine & - & 1.66 & 1.7 \\
\hline Alanine & - & 1.82 & 1.98 \\
\hline Tyrosine & - & 1.21 & 1.17 \\
\hline \multicolumn{4}{|l|}{ Indispensable amino acids (\%) } \\
\hline Threonine & - & 1.26 & 1.3 \\
\hline Arginine & - & 2.24 & 2.08 \\
\hline Histidine & - & 0.78 & 0.8 \\
\hline Methionine & - & 0.48 & 0.55 \\
\hline Valine & - & 1.8 & 1.85 \\
\hline Phenylalanine & - & 1.77 & 1.76 \\
\hline I-leucine & - & 1.68 & 1.53 \\
\hline Leucine & - & 2.79 & 2.9 \\
\hline Lysine & - & 1.86 & 1.66 \\
\hline
\end{tabular}

Table 4. Essential amino acids digestibility of biofloc meal diet by Pacific white shrimp (Litopenaeus vannamei)

\begin{tabular}{lll}
\hline & Reference & Microbial meal \\
\hline Threonine & $53.63 \pm 1.24^{\mathrm{a}}$ & $70.44 \pm 3.46^{\mathrm{b}}$ \\
Arginine & $58.52 \pm 2.02^{\mathrm{a}}$ & $73.63 \pm 2.06^{\mathrm{b}}$ \\
Histidine & $25.10 \pm 2.01^{\mathrm{a}}$ & $51.96 \pm 5.62^{\mathrm{b}}$ \\
Methionine & $51.20 \pm 0.01^{\mathrm{a}}$ & $74.02 \pm 5.07^{\mathrm{b}}$ \\
Valine & $54.27 \pm 2.80^{\mathrm{a}}$ & $65.47 \pm 7.20^{\mathrm{a}}$ \\
Phenylalanine & $52.96 \pm 5.60^{\mathrm{a}}$ & $64.45 \pm 8.29^{\mathrm{a}}$ \\
I-leucine & $54.39 \pm 3.67^{\mathrm{a}}$ & $69.99 \pm 3.97^{\mathrm{a}}$ \\
Leucine & $54.62 \pm 4.07^{\mathrm{a}}$ & $70.11 \pm 4.37^{\mathrm{b}}$ \\
Lysine & $68.59 \pm 9.38^{\mathrm{a}}$ & $71.19 \pm 2.03^{\mathrm{a}}$ \\
\hline
\end{tabular}

shrimp is presented in Figure 2 and amino acids digestibility is presented in Figure 3.

\section{Discussion}

Shrimp survival, growth and feed conversion ratio in the treatment with microbial meal based diet were comparable $(\mathrm{P}>0.05)$ to those of the reference diet. This indicates that the inclusion of microbial meal in the diets did not compromise the shrimp survival and growth. The digestibility of feed raw materials is one of the most important aspects in determining the potential use of a raw material in the diet of aquaculture species, which represent the bioavailability of nutrients that can be absorbed by the animals (Yang et al., 2009). Raw materials with high digestibility are recommended to use to reduce the accumulation of waste coming from the undigested feed materials, which ultimately contribute to the water quality deterioration (Yang et al., 2009). Dry matter, protein and lipid digestibility of shrimp diet containing microbial meal were comparable to that of the reference diet. This strongly indicates that major nutrients in microbial meal could be digested by the shrimp. The digestibility of dry matter of biofloc meal $(54.9 \%)$ in the present 

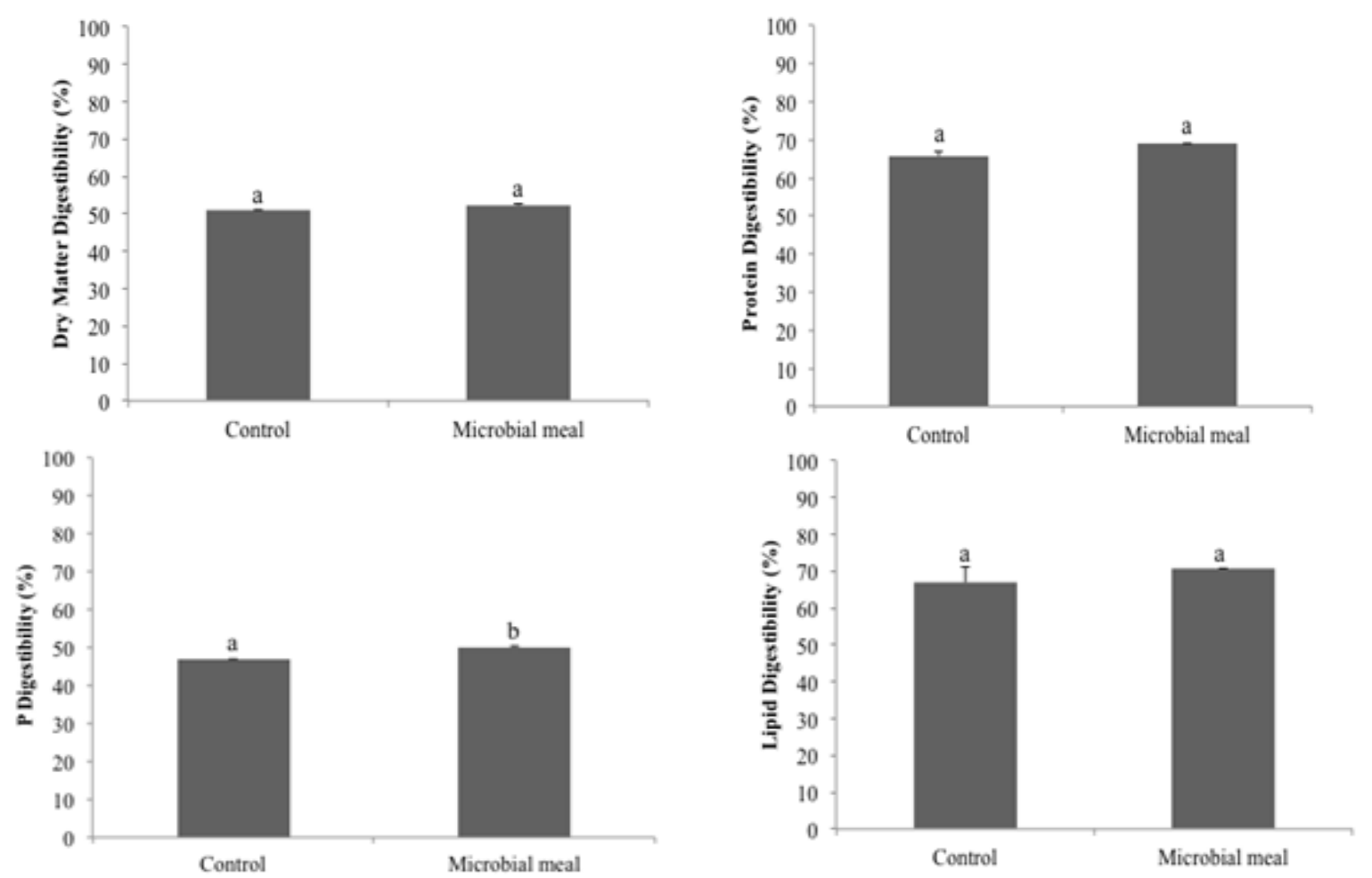

Figure 1. Digestibility (\%) of diet containing microbial meal in Pacific white shrimp (Litopenaeus vannamei): (a) Dry matter, (b) protein, (c) lipid, and (d) phosphorus.

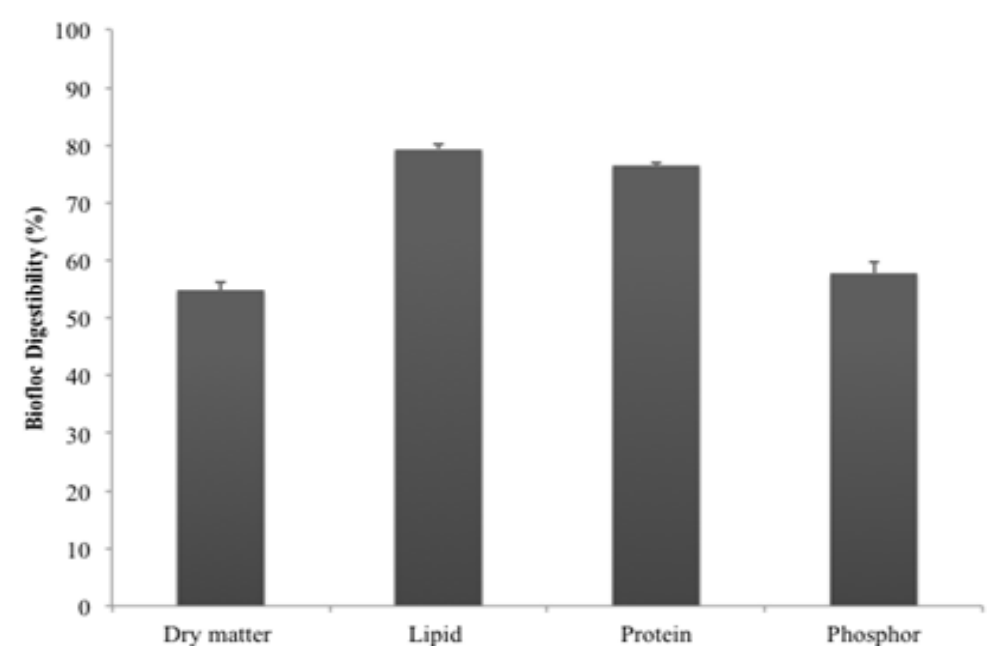

Figure 2. Microbial meal dry matter, lipid, protein and phosphorus digestibility of microbial meal collected from biofloc-based catfish production.

study was relatively low compared to other shrimp feed raw material such as fishmeal and soybean meal. However, it was comparable to those of shrimp by product meal $(52.8 \%)$ and meat bone meal $(56.3 \%)$. Indeed, the microbial meal collected from biofloc-based catfish culture in this study contained considerable levels of fibre and ash, which might limit the digestibility of this ingredient by the shrimp. Comparable result on biofloc dry matter digestibility was reported in tilapia, where biofloc produced from a sequencing batch reactor had a ADC of 57.28-58.64\% (Liu et al., 2016)
A recent study by Sabry et al. (2015) reported that protein apparent digestibility coefficient of biofloc meal produced by using shrimp culture wastewater and clean seawater were $26 \%$ and $25.7 \%$, respectively, which was almost thrice lower than that observed in the present study (76.3\%). Generally, the recommended level of ADC of crude protein in feed raw materials for shrimp diet is above 50\% (NRC, 2011). In comparison with other raw materials for shrimp feed, the protein digestibility of biofloc meal in this study was comparable to that recorded of poultry meat meal and meat bone meal (Yang et al., 2009), poultry 


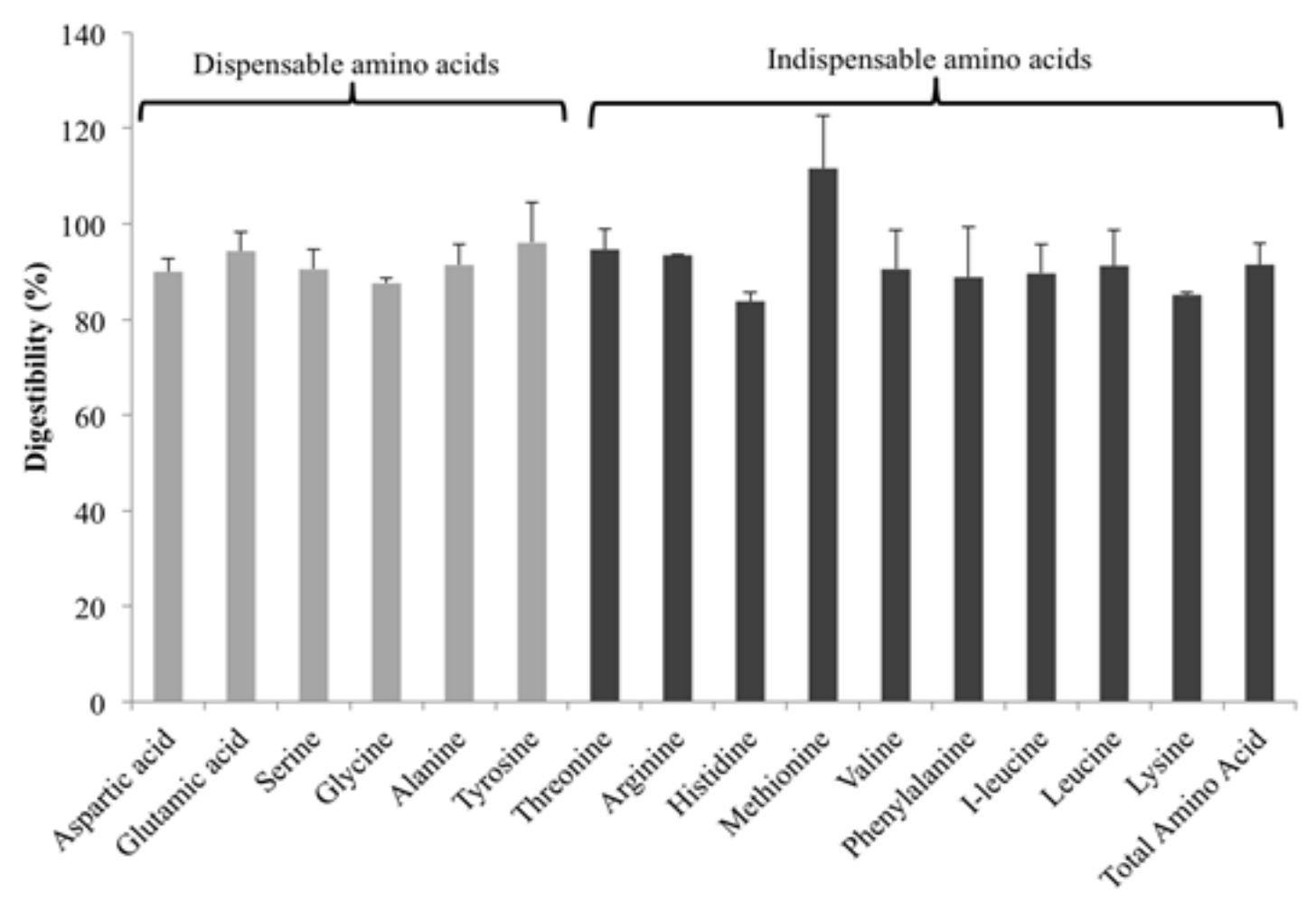

Figure 3. Amino acids digestibility of microbial meal collected from biofloc-based catfish production in Pacific white shrimp.

by product meal and hydrolysed feather meal (De Carvalho et al., 2016). Lipid digestibilities of biofloc meals produced by using shrimp culture wastewater and clean seawater $(78.9 \%$ and $67.9 \%$, respectively) were also slightly lower than that of the present study (79.3\%). These discrepancies in the digestibility of different bioflocs meals might indicate that the source of bioflocs meal could have some significant effects on the nutritional quality of bioflocs, which may further influence the digestibility of the material and its utilization by the cultured organism. Interestingly, $\mathrm{P}$ digestibility in microbial meal-based diet was significantly higher than that of the reference diet. This might be attributed to the higher digestible $\mathrm{P}$ available in microbial floc meal. Ekasari (2014a) suggested that the microbes associated in bioflocs could produce microbial phytase that convert the phytic acid, an indigestible $\mathrm{P}$ in plant-based feed raw material, into more digestible $\mathrm{P}$ for the cultured organism.

Although protein digestibility was comparable between the microbial meal diet and the reference diet, the digestibility of all essential amino acids in microbial meal-based diet were higher than those of the reference diet and for some essential amino acids and the differences were significant $(\mathrm{P}<0.05)$. The lowest and the highest amino acids digestibilities of biofloc meal in shrimp were recorded in histidine and methionine. Although there was no study has been conducted to elucidate the amino acids digestibility of microbial meal, these results strongly confirmed previous study suggesting that microbial meal is a good protein source for shrimp (Ekasari et al., 2014a).

\section{CONCLUSION}

In conclusion, the present study demonstrated that white shrimp juvenile are able to digest the protein, lipid and phosphorus of bioflocs meal, and the use of bioflocs meal in the diet at about $30 \%$ resulted in comparable growth to that of the control.

\section{REFERENCES}

Anand PSS, Kohlil MPS, Kumar S, Sundaray JK, Dam Roy S, Venkateshwarlu G, Sinha A, Pailan GH. 2014. Effect of dietary supplementation of biofloc on growth performance and digestive enzyme activities in Penaeus monodon. Aquaculture 418 - 419: 108 - 115 .

[AOAC] Association of Official Analitycal Chemist. 2005. Official Methods of Analysis, 
17th ed. Gaithersburg (USA): Association of Official Analytical Chemists.

Bauer W, Prentice-Hernandez C, Tesser MB, Wasielesky W, Poersch LHS. 2012. Substitution of fishmeal with microbial floc meal and soy protein concentrate for the Pacific white shrimp Litopenaeus vannamei. Aquaculture 342-343: 112-116.

De Carvalho RA, Ota RH, Kadry VO, Tacon AG, Lemos D. 2016. Apparent digestibility of protein, energy and amino acids of six protein sources included at three levels in diets for juvenile white shrimp Litopenaeus vannamei reared in high performance conditions. Aquaculture 465: 223 - 234.

Cho CY, Slinger SJ. 1979. Apparent digestibility measurement in feedstuff for rainbow trout. In: Halver JE, Tiews K (eds). Finfish Nutrition and Fish Food Technology Vol. 2. Berlin: Heenemann GmbH. pp. 239-247.

De Schryver P, Crab R, Defoirdt T, Boon N, Verstraete W. 2008. The basics of bio-flocs technology: The added value for aquaculture. Aquaculture 277: 125-137.

Ekasari J, Crab R,, Verstraete W. 2010. Primary nutritional content of bio-flocs cultured with different organic carbon sources and salinity. Hayati Journal of Biosciences 17: 125-130.

Ekasari J, Angela D, Waluyo SH, Bachtiar T, Surawidjaja EH., De Schryver P. 2014a. The size of biofloc determines the nutritional composition and the nitrogen recovery by aquaculture animals. Aquaculture 426: 105-111.

Ekasari J, Azhar MH, Surawidjaja EH, Nuryati S, De Schryver P, Bossier P. 2014b. Immune response and disease resistance of shrimp fed biofloc grown on different carbon sources. Fish \& Shellfish Immunology 41: 332 - 339.

Glencross BD, Irvin S, Arnold SJ, Bourne NB, Preston NP. 2014. Effective use of microbial biomass products to facilitate the complete replacement of fishery resources in diets for the black tiger shrimp, Penaeus monodon. Aquaculture 431: 12-19

Glencross BD, Arnold S, Irvin S. 2015. Bioactive factors in microbial biomass have the capacity to offset reductions in the level of protein in the diet of black tiger shrimp, Penaeus monodon. Aquaculture 446: 74 - 79.

Kheti B, Kamilya D, Choudhury J, Parhi J, Debbarma M, Singh ST. 2017. Dietary microbial floc potentiates immune response, immune relevant gene expression and disease resistance in rohu, Labeo rohita (Hamilton, 1822) fingerlings. Aquaculture 468: 501-507. Kuhn DD, Lawrence AL, Boardman GD, Patnaik S, Marsh L, Flick GJ. 2010. Evaluation of two types of bioflocs derived from biological treatment of fish effluent as feed ingredients for Pacific white shrimp, Litopenaeus vannamei. Aquaculture 303: 28-33.

Kuhn DD, Lawrence AL, Crockett J, Taylor D. 2016. Evaluation of bioflocs derived from confectionary food effluent water as a replacement feed ingredient for fishmeal or soy meal for shrimp. Aquaculture 454: 66-71.

Liu W, Luo G, Tan H, Sun D. 2016. Effects of sludge retention time on water quality and bioflocs yield, nutritional composition, apparent digestibility coefficients treating recirculating aquaculture system effluent in sequencing batch reactor. Aquacultural Engineering 72: $58-64$.

Lobato OSC, Ribeiro FDAS, Miranda-Baeza A, Emerenciano MGC. 2019. Production performance of Litopenaeus vannamei (Boone, 1931) fed with different dietary levels of tilapia processing waste silage reared in biofloc system using two carbon sources. Aquaculture 501: 515-518.

Molina-Poveda C, Lucas M, Jover M. 2015. Utilization of corn gluten meal as a protein source in the diet of white shrimp Litopenaeus vannamei. Aquaculture Nutrition 21: 824-834.

[NRC] National Research Council. 2011. Nutrient Requirements of Fish and Shrimp. Washington DC (US): National Academies Press.

Sabry NH, Santaella ST, Nunes AJP. 2015. Bioavailability of crude protein and lipid from biofloc meals produced in an activated sludge system for white shrimp, Litopenaeus vannamei. Revista Brasileira de Zootecnia 44: 269-275.

Simon CJ, Blyth D, Fatan NA, Suri S. 2019. Microbial biomass (Novacq $^{\mathrm{TM}}$ ) stimulates feeding and improves the growth performance on extruded low to zero-fishmeal diets in tilapia (GIFT strain). Aquaculture 501: 319324.

Takeuchi T. 1988. Laboratory Work Chemical Evaluation of Dietary Nutrition. p. 179-229. In Watanabe T. Fish Nutrition and Mariculture. Tokyo (JP): Kanagawa International Fisheries Training Center. 
Van Den Hende S, Claessens L, De Muylder E, Boon N, Vervaeren H. 2014. Microalgal bacterial flocs originating from aquaculture wastewater treatment as diet ingredient for Litopenaeus vannamei (Boone). Aquaculture Research 47: 1075-1089.

Yang Q, Zhou X, Zhou Q, Tan B, Chi S, Dong X. 2009. Apparent digestibility of selected feed ingredients for white shrimp Litopenaeus vannamei, Boone. Aquaculture Research 41:78-86.
Xu WJ, Pan LQ. 2013. Enhancement of immune response and antioxidant status of Litopenaeus vannamei juvenile in biofloc-based culture tanks manipulating high $\mathrm{C} / \mathrm{N}$ ratio of feed input. Aquaculture 412: 117-124.

Xu WJ, Pan LQ. 2014. Evaluation of dietary protein level on selected parameters of immune and antioxidant systems, and growth performance of juvenile Litopenaeus vannamei reared in zero-water exchange biofloc-based culture tanks. Aquaculture 426: 181-188. 